West German science council out on strike

\section{Munich}

THE Wissenschaftsrat, founded in 1957 as an independent advisory council on science to the West German federal and Länder governments, has for the first time in its history gone on strike. The 22member scientific review commission walked off the job at a meeting in Berlin in mid-November and is unlikely to resume its duties until next year.

The group walked out to protest at a budgetary manoeuvre of the West German Bundestag (parliament) that would move the position of general-secretary of the science council out of the (independent) West German president's office into the (partisan) federal education Ministry. The scientific members called the move "an attack on the independence of the Wissenschaftsrat as a whole".

The current troubles began when the Bundestag budget committee reduced the position of general-secretary from "B9" - a political appointee earning as much as DM11,000 per month - to "B7" - a public servant earning about DM1,000 less. But the office of the president refused to allow a $\mathrm{B} 7$ position in its budget, as such an employee has lifelong tenure. So the position ended up in the education ministry. The decisive blow came on 10 November, when an education ministry official informed the council that the position had been reduced even further, to B6, and that it would remain in the education ministry. The scientific commission decided unanimously an hour later to strike.

The commission, which is scheduled to meet again next Monday, the 12 December, has declared its willingness to compromise in case the general-secretary's position cannot be reassigned to the office of the president. The Länder education ministers have promised to support the striking members of the council in negotiating with their respective ministerpresidents.

In the meantime, scientific review of several institutions has had to be postponed, among them the German Cancer Research Centre. Even more importantly, the necessary Wissenschaftsrat approval could not be given for fourteen new Sonderforschungsbereiche (special collaborative programmes) of the Deutsche Forschungsgemeinschaft, nor for a DM500 million university investment plan.

The earliest possible date for a settlement is 15 December, when the ministerpresidents are scheduled to meet in Hamburg.

Steven Dickman

\title{
National Institutes of Health stop Harvard researchers' grants
}

Boston

DRAMATIC action marked a widely publicised case of alleged scientific misconduct last week, when the National Institutes of Health (NIH) terminated hundreds of thousands of dollars in grants to Scheffer C. G. Tseng and Kenneth R. Kenyon. The two scientists, both affiliated to Harvard University, are alleged to have profited from business interests in a drug that they were responsible for testing and to have delayed publication of data showing that the drug was ineffective.

But the severity of the NIH decision was soon under fire. John Dingell (Democrat, Michigan) was "horrified", according to a staff member on the energy and commerce subcommittee on oversight and investigations which Dingell chairs. Although the subcommittee, which is conducting its own investigation into the case, has previously criticized NIH for dragging out their investigations of scientific misconduct, the subcommittec thinks NIH have acted too hastily this time. As well as the congressional inquiry, two separate $\mathrm{NIH}$ investigations are still under way.

NIH cut off funding for the final two years of a five-year, $\$ 850,000$ grant to Tseng, now a research scientist at the University of Miami. According to an official Harvard statement, the conflict of interest arose in 1985 when Tseng, a former Harvard scientist, and his supervisor, Kenyon, acquired stock in a company that owned the rights to a Vitamin-A based ophthalmic ointment whose efficacy they were testing (see Nature 335, 754; 27 October 1988). NIH also suspended consideration of a

\section{Harvard resignation}

\section{Boston}

IN a second case of alleged scientific misconduct at Harvard University, Dr Shervert Frazier, psychiatrist at Harvard Medical School and former director of the National Institute of Mental Health, resigned after admitting that he had plagiarized large sections of four review articles published between 1960 and 1975 .

Frazier's decision to resign has upset colleagues, who consider resignation a stiff penalty given that none of the plagiarized material reported original research data.

Daniel C. Tosteson, dean of Harvard Medical School, emphasized to reporters that Harvard's rules on plagiarism "are pretty harsh". Tosteson says that Harvard guidelines to students state explicitly that plagiarism will mean expulsion. "Are we to say that it's OK for a professor?" he asks.

Seth Shulman
$\$ 191,000$ grant application submitted by Kenyon and insisted that he be replaced as the director of a NIH-funded postdoctoral fellowship programme at the Eye Research Institute, a private organization associated with the hospital. Kenyon has held the directorship for almost a decade.

Jack McLaughlin, associate director of the National Eye Institute of $\mathrm{NIH}$, stresses that the cessation of funding represented "no presumption of any wrongdoing" by Tseng and Kenyon. But Tseng's lawyer, Robert Kasky, argues that NIH's termination of funds is "unreasonable, unjust and unfair" given that "the investigation of alleged improprieties is not nearly over". Kasky is not alone in his concern. Charles L. Schepens, Kenyon's colleague and president of the NIH-funded Eye Research Institute in Boston, likened the suspension of funds to the "mass hysteria" of the McCarthy era.

But Katherine L. Bick, NIH deputy director for extramural research, disagrees. "We felt it was proper", she says, "to simply stop where we are until we know what is going on." She emphasizes that the move does not reflect a policy change and is not without precedent. On other occasions, she says NIH have decided to "not make new awards" when questions of impropriety have been raised.

Before NIH took action, Daniel C. Tosteson, dean of Harvard Medical School, disclosed that Harvard's internal investigation found Tseng and Kenyon had never reported the potential conflict of interest. According to Tosteson, "proper research procedures were not followed" when the researchers altered their study's original protocol without notifying Harvard's review board. Tosteson states that he is "concerned about the damage this incident does to the medical community", adding that "such episodes threaten the public trust and the integrity of medical research".

Meanwhile, in a more recent development, an investor has sued Tseng, Kenyon and others, including Johns Hopkins researcher A. Edward Maumenee, and officials of the drug company in question - Spectra Pharmaceuticals Services, Inc. - for defrauding him in his purchase of Spectra stock. The class-action suit, filed in a US district court, alleges that the scientists presented a distorted and misleading picture of the eye ointment's effectiveness. Claiming that the entire future of the small company was predicated upon the drug, the suit seeks retribution on behalf of the hundreds of people who purchased stock in the company based on the allegedly misleading information. 